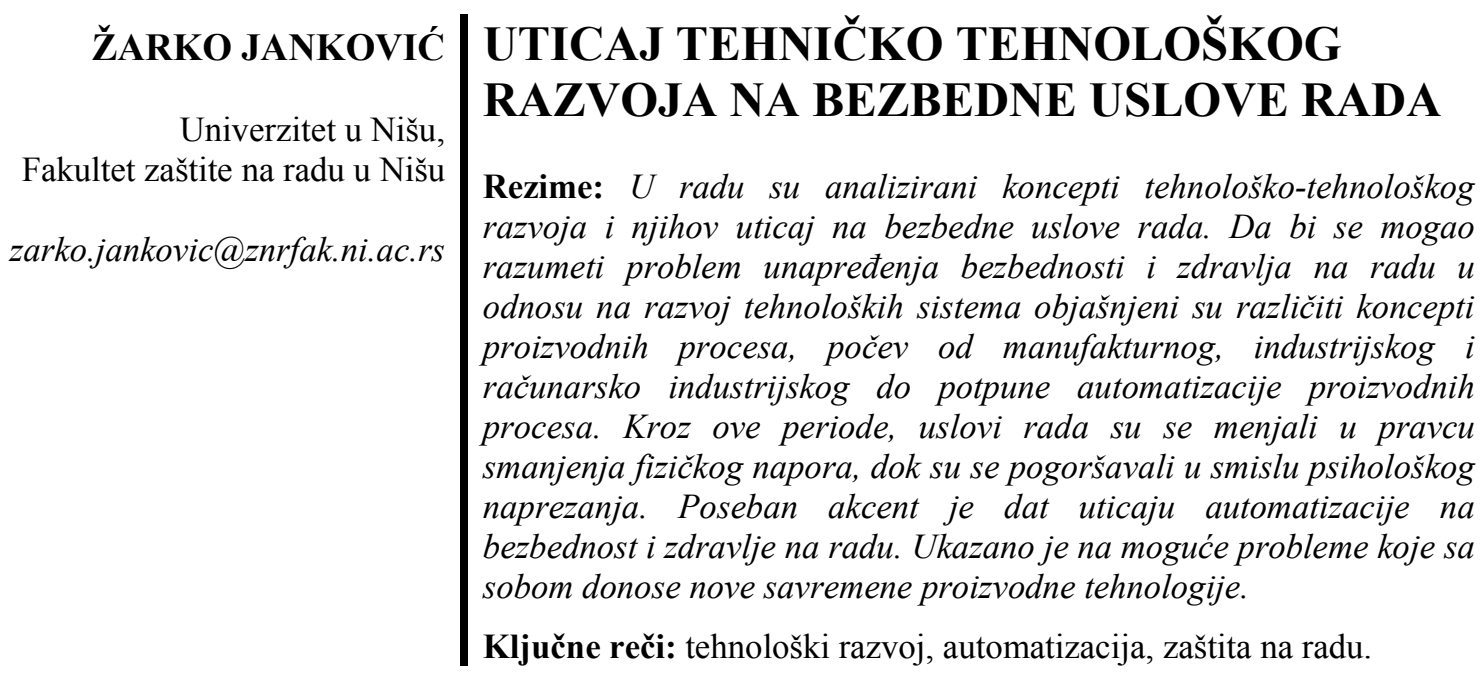

\section{UVOD}

U težnji za lakšom obradom proizvoda, čovek je uvek vodio računa o tome da rad bude što lakši i bezbedniji. Tu se, u stvari, nalaze i prvi začeci zaštite na radu, koja je, zajedno sa razvojem proizvodnih snaga, evoluirala u jednu interdisciplinarnu nauku. Cilj ovog rada je da istakne određena korelaciju između tehničkotehnološkog razvoja i uticaj bezbedne uslove rada. Prikaz tehničko-tehnološkog razvoja u odnosu na sistem primenjene zaštite prikazan je na slici 1 .

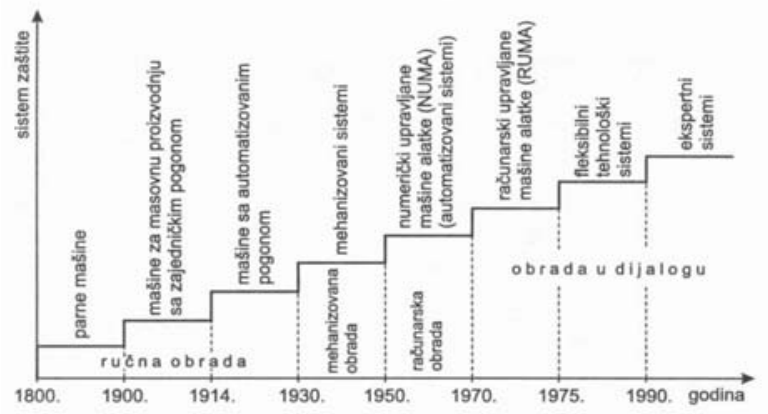

Slika1. Razvoj tehničko-tehnoloških sistema

Važan uticaj na razvoj tehničko-tehnoloških sistema imala je industrijska proizvodnja. Međutim, u današnje vreme razvoj industrijske proizvodnje, predstavlja uvođenje numeričkog upravljanja tehničkim sistemima, kojim se postiže automatsko upravljanje bez fizičkog opterećenja i zamaranja radnika. Početak automatizovanog razvoja tehničkih sistema datira od 1949. godine prošlog veka. Intenzivan razvoj elektronike je omogućio automatsko upravljanje procesom proizvodnje. Poseban doprinos ovakvom procesu proizvodnje i razvoju tehničko-tehnološki sistema ogleda se u tome što je ovaj sistem postao jeftiniji, pouzdaniji i bezbedniji.

Značajan korak u daljem razvoju tehničko-tehnoloških sistema predstavlja konstruisanje računski upravljanih mašina $i$ uređaja. Uvođenjem fleksibilne automatizacije, kombinovanjem jedinica za numeričko upravljanje računara, omogućeno je manje fizičko naprezanje radnika i njegovo udaljavanje iz opasnih procesa rada. Viši nivo razvoja tehničko-tehnoloških sistema predstavlja uvođenje robota $u$ proces proizvodnje. Na ovaj način je omogućen razvoj automatizovanih proizvodnih sistema koji vrše integraciju planiranja proizvodnje i praćenje procesa rada [1].

Za totalno automatizovani vid proizvodnje potrebno je izvršiti dalje povećanje automatizacije. Ovakav pristup bi u budućnosti u potpunosti eliminisao prisustvo radnika (operatora) u neposrednoj proizvodnji i u zoni opasnosti, kao i mnogobrojne štetnosti po zdravlje radnike. Ugroženost radnika od mogućih povređivanja mehaničkog dejstva kao i svi drugi rizici bi bili svedeni na najmanju moguću meru ili potpuno eliminisani.

\section{OSNOVNI PROBLEMI TEHNIČKO TEHNOLOŠKOG RAZVOJA}

Sagledavanjem savremenih dostignuća i nastalih promena u domenu degradacije prirode, uočava se sva tragika utopističkih filozofija poimanja kvaliteta čovekovog života. S tim u vezi, tehničko tehnološki razvoj se u dvadest prvom veku može sagledati kroz:

a) globalne probleme opstanka,

b) proces prirodnih i veštačkih sistema, i

c) razvoj novih tehnologija.

\section{A) Globalni problemi opstanka}

Ako se uzmu u obzir globalni problemi opstanka čoveka od njegovog postanka do danas dolazi se do važnih spoznaja čiji je prikaz dat na slici 2 .

Oznake skraćenica: KK-kosmičke kataklizme; PKplanetarne stihijske nepogode i katastrofe (potresi, poplave, i dr.); GL - glad izazvana nestašicom hrane u širim područjima; RT - uništavanje čoveka od strane čoveka ratovanjem; EP - epidemije;ŽS - uništavanje čoveka od strane životinjskog sveta; EK-ekološki problemi; MA-problemi materijala; EN-energetski problemi; DE-demografski problemi i MO-moralne 
degradacije. Ovi problemi se odnose na sve slojeve ljudskog društva.

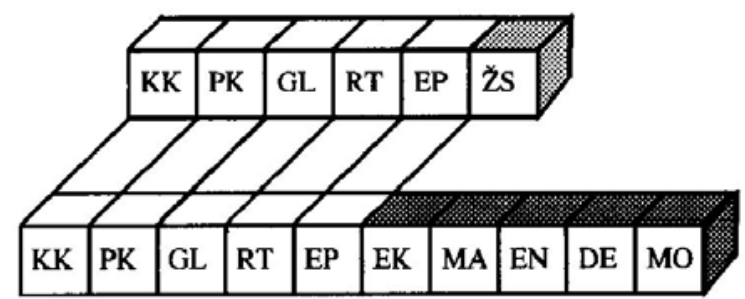

Slika 2. Globalni problemi opstanka [1]

Analiziranjem kvaliteta čovekovog života i globalnih problema opstanka, kao i rezultata njegove delatnosti koji su doveli do civilizacijskog progresa, dolazi se do poražavajućih konstatacija:

1) Čovek je rešio samo jedan globalni problem, i to opasnost od životinjskog sveta - (ŽS);

2) Stvorio je pet novih, veoma ozbiljnih i izraženo krupnih problema i to: (ekološki - EK; materijalni MA; energetski - EN; demografski - DE; i moralni $\mathrm{MO}$;

3) Uvećao tri problema iz prvog perioda razvoja, i to: probleme gladi - GL; rata - RT; i epidemija - EP.

Pored iznetih poražavajućih konstatacija, problem postaje složeniji kada se navedeni globalni problemi opstanka čoveka podele u dve grupe, i to:

(1) Osnovni problemi - koji su nastali nezavisno od delatnosti i volje čoveka, $\mathrm{i}$

(2) Dopunski problemi - koje je stvorio čovek svojim nesavesnim delovanjem.

Ova dva problema su do početka XXI veka proučavana odvojeno i smatralo se da nisu međusobno zavisni. Međutim, razvojem tehnologija - nažalost - uspostavlja se, u negativnom smislu, zavisnost osnovnih globalnih problema od delatnosti čoveka. Kao dokaz dovoljna je spoznaja da su se nekada planetarne nepogode i katastrofe dešavale nezavisno od čoveka, što danas nije uvek slučaj.

\section{B) Procesi prirodnih i veštačkih sistema}

U prirodi se stalno odvijaju dva procesa suprotnog smera, čime je obezbeđen zatvoren ciklus kruženja materije. Ovi procesi se karakterišu:

- usložnjavanjem prirodnih funkcionalnih elemenata i sistema, tj. stvaranjem sistema višeg nivoa od elemenata i sistema nižeg nivoa, $\mathrm{i}$

- njihovim uprošćavanjem, odnosno, razgrađivanjem složenijih sistema - sistema višeg nivoa - u sisteme i elemente nižeg nivoa, koji time postaju sirovinska baza za ponovno usložnjavanje.

Čovek je proučavajući prirodu i otkrivajući njene zakone upao u zamku. Ne sagledavši i ne spoznavši prirodne mehanizme i principe u potpunosti, njene procedure i zakone, stvorio je svoje funkcionalne sisteme - veštačke sisteme - koji su uglavnom složeni po svom karakteru. Rezultat ovakvih čovekovih aktivnosti su proizvodne tehnologije koje predstavljaju otvorene sisteme, a oni su vinovnici nagomilanih problema koji ugrožavaju opstanak čoveka na Zemlji, jer su procesi reciklaže u nekim tehnologijama nepoznati, minorni ili se ne sprovode.

\section{C) Razvoj novih tehničkih sistema}

Osnove razvoja tehničko-tehnoloških sistema u periodu koji je iza nas činile su:

- zablude da su prirodni resursi beskonačno veliki i da razvoj tehnike i tehnologije neće izazvati promene stanja u biosferi;

- naučna saznanja koja su odgovarala proizvodnim tehnologijama, i

- tehničko-ekonomski kriterijumi vrednovanja proizvodnih tehnologija, baziranih na pohlepi čoveka.

Posledice ovakvog razvoja su:

- sagledavanje vremena - bliske budućnosti - u kome će biti iscrpljeni prirodni resursi gradivnih i energetskih materijala, $\mathrm{i}$

- ozbiljni poremećaji stanja biosfere i alarmirajuće, sve progresivnije, nestajanje čitavih eko-zajednica.

Ubrzani tehničko-tehnološki progres uslovljen razvojem novih tehnologija, materijala i informacionih sistema doveo je do promena u sadržaju i karakteru ljudskog rada, kao sastavnog elementa svakog proizvodnog tehnološkog sistema. Proizvodni tehnološki sistem kao skup ulaznih elemenata (materijal, sredstva rada, projektovane tehnologije, ljudski rad) i izlaznih elemenata (gotovi proizvodi) je okruženje koje presudno utiče na projektovanje sistema zaštite. Kakav će sistem zaštite da se primeni zavisi od opasnosti i štetnosti koje sa sobom nose nove tehnologije [5].

Optimalna raspodela funkcija između čoveka i mašine ukazuje na relativne prednosti čoveka u odnosu na mašinu. Čovek je jedini sposoban da reaguje $u$ promenljivim uslovima i pronalazi najracionalnija rešenja za izbegavanje mogućih opasnosti i štetnosti.

Mašina istovremeno može obavljati više različitih operacija, pa u tom pogledu ima prednosti u odnosu na čoveka, koji se u jednom momentu može usredsrediti samo na obavljanje jednog zadatka. Osim toga, mašine su osetljive, one reaguju i na one faktore koji su ispod praga osetljivosti čovekovih čulnih organa pa i na one nadražaje (signale) koji mogu biti udaljeni kilometrima od mesta lokacije mašine (npr, daljinsko upravljanje).

Razvojne mogućnosti tehnološke opreme stvaraju raskorak između potencijalnih mogućnosti mašine i krajnih psiho-fizioloških mogućnosti čoveka. U većini slučajeva, mašina smanjuje zahteve čoveka $u$ fiziološkom pogledu, ali ih znatno povećava $u$ psihološkom. Polazeći od čovekovih nedostataka $u$ odnosu na mašinu, pri projektovanju i konstrukciji mašine treba nastojati da se sve one operacije koje prevazilaze granicu psiho-fizičkih mogućnosti čoveka prenesu na mašinu. Na taj način će se pronaći najpovoljnije mogućnosti za optimalnu i efikasnu međuzavisnost elemenata u sistemu ,čovek-mašina“. 


\section{PROCES RAZVOJA SISTEMA ZAŠTITE U INDUSTRIJI}

Za smanjenje proizvodnih troškova po jedinici proizvoda, najare je bilo potrebno konstruisati mašine specijalne namene, pri čemu su se postavljali zahtevi za automatizacijom radnog ciklusa, odnosno vršenjem pojedinih operacija automatski. Ove navedene mogućnosti predstavljaju osnovne principe na kojima su se razvile specijalne mašine. Prvobitne specijalne mašine su građene strogo namenski, isključivo za izradu predmeta jednog tipa. Svaka mašina je u stvari bila prototip i građena je kao unikat. Međutim, mašine projektovane na ovim principima pokazale su prednosti ne samo sa gledišta ekonomičnosti i produktivnosti, već i sa gledišta ispunjavanja sve većih zahteva u pogledu tačnosti, manjeg angažovanja radnika u procesu obrade, a samim tim i smanjenja mogućih povreda na radu.

Osnovu industrijskih sistema čine sredstva rada. S obzirom na specifičnosti i ispoljene određene karakteristike u toku razvoja sredstava rada i njihovog uticaja na industrijske sisteme, mogu se izdvojiti tri razvojna perioda sredstava za rad. $U$ tabeli 1 su dati razvojni periodi sredstava rada po fazama sa najvažnijim karakteristikama svake faze.

Tabela 1. Faze razvoja sredstava rada sa najvažnijim karakterstikama

\begin{tabular}{|c|c|c|}
\hline Faza & $\begin{array}{l}\text { Sredst } \\
\text { va } \\
\text { rada }\end{array}$ & KARAKTERISTIKE \\
\hline I & 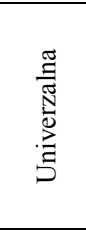 & $\begin{array}{l}\text { - Otpočinje uvođenje mašina u proizvodni } \\
\text { proces. } \\
\text { - Izvor energije postaje mašina umesto čovek. } \\
\text { - Zadržava se zanatski način proizvodnje. } \\
\text { - Mašina je opšte namene - univerzalnog tipa. } \\
\text { - Radnik još radi sve operacije u procesu } \\
\text { oblikovanja proizvoda. }\end{array}$ \\
\hline II & 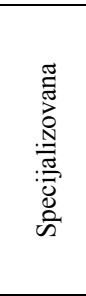 & $\begin{array}{l}\text { - Specijalizacija mašina po tehnološkim } \\
\text { operacijama. } \\
\text { - Radnik opslužuje mašinu materijalom koji } \\
\text { se obrađuje, nadzire rad mašine i vrši } \\
\text { popravak mašine. } \\
\text { - Rad čoveka postaje indirektan. } \\
\text { - On ne vrši obradu direktno na predmetu } \\
\text { rada, već to čini mašina koju on snabdeva, } \\
\text { nadzire i podešava. }\end{array}$ \\
\hline III & 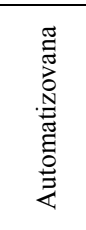 & $\begin{array}{l}\text { - Čovek ne učestvuje u operacijama obrade. } \\
\text { - Automatizovani su: rad mašine, komande, } \\
\text { tokovi materijala po svim fazama obrade. } \\
\text { - Radnik nema fizičko naprezanje, rizik od } \\
\text { mehaničkih opasnosti je neznatan. } \\
\text { - Povećan je problem psihofiziološkog napora } \\
\text { i mentalnog opterećenja. }\end{array}$ \\
\hline
\end{tabular}

$\mathrm{U}$ odnosu na pomenute tri faze razvoja sredstava rada, u vremenu u kome živimo, važno je istaći treću fazu automatizovanog načina proizvodnje. U trećoj fazi automatizovanog procesa rada, radno mesto i parametri radne sredine se suštinski menjaju, te se menja $\mathrm{i}$ uzajamni odnos između sredstava rada i radnika, menja se mesto, položaj i uloga radnika u radnom prostoru. Mogućnosti ugrožavanja radnika se zbog izmenjenih uslova $u$ radnoj sredini menjaju, jer su promenjeni i uzročnici koji mogu dovesti do njegovog fizičkog ili mentalnog povređivanja.
Dalji razvoj tehnoloških sistema i opreme za rad stvara raskorak između potencijalnih mogućnosti mašine i krajnjih psiho-fizioloških mogućnosti čoveka. U većini slučajeva, mašina smanjuje zahteve čoveka $u$ fiziološkom pogledu, ali ih znatno povećava $u$ psihološkom. Polazeći od čovekovih nedostataka $u$ odnosu na mašinu, pri projektovanju i konstrukciji mašine treba nastojati da se sve one operacije koje prevazilaze granicu psiho-fizičkih mogućnosti čoveka prenesu na mašinu. $\mathrm{Na}$ taj način će se pronaći najpovoljnije mogućnosti za optimalnu i efikasnu međuzavisnost elemenata u sistemu ,čovek-mašina” [1].

\section{STEPEN ZAŠTITE U ZAVISNOSTI OD VRSTE TEHNIČKIH SISTEMA}

Od interesa je istaći značajne razlike koje postoje između industrijske proizvodnje sa univerzalnim mašinama (U), specijalnim mašinama (S) i automatizovanim sistemima (A).

Polazeći od ove globalne podele mašina (univerzalne, specijalne i automatizovane), njihovih opasnih zona i prostorno posmatrano položaja radnika na radnom mestu, kao i njegove uloge u proizvodnom procesu, dolazi se do saznanja da se opslužioc (operator) mašine sa njenim usložnjavanjem od univerzalne do visoko automatizovane sve više udaljavao od opasnog prostora, što se manifestuje smanjivanjem rizika od povređivanja mehaničkog dejstva.

Imajući izneto $\mathrm{u}$ vidu, moguće je uvesti parametar $\left(\mathrm{S}_{\mathrm{z}}\right)$ koji predstavlja stepen zaštite radnika od povređivanja mehaničkog dejstva, čije se vrednosti uglavnom kreću u granicama; $0 \leq \mathrm{S}_{\mathrm{z}} \leq 1$. Ukoliko stepen zaštite teži nuli $\left(S_{z} \Rightarrow 0\right)$, znači da nisu ugrađeni zaštitni sistemi na mašini. Međutim, ako ovaj parametar teži jedinici (S $\Rightarrow 1$ ), znači da je sistem zaštite makimalan.

Linearizacijom zakona promene stepena zaštite $\left(\mathrm{S}_{\mathrm{z}}\right)$, a zavisno od vrste mašine i primenjenih sistema tehničke zaštite dobija se zakonitost čija je grafička interpretacija prikazana na slici 3 .

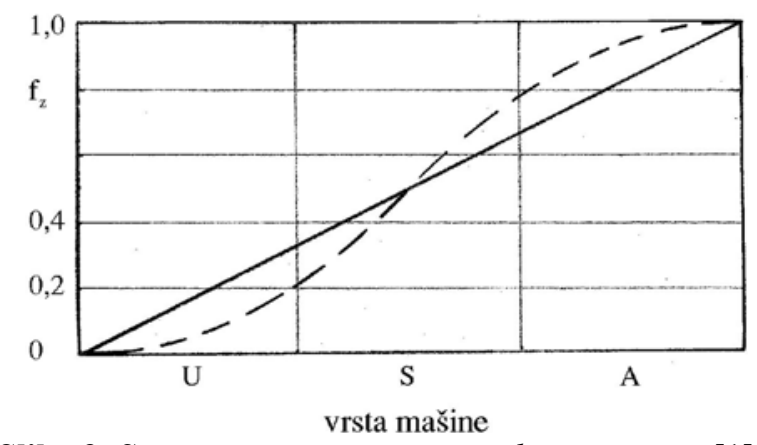

Slika 3. Stepen zaštite u zavisnosti od vrste mašine [1]

$U$ - univerzalne, $S$-specijalne, A -automatske mašine

Iz linearizovanog zakona promene parametra stepena zaštite $\left(\mathrm{S}_{\mathrm{z}}\right)$ datog na slici 3 , dolazi se do toga da su njegove vrednosti za pojedine vrste mašina, i to za: 
$\begin{array}{lll}\mathrm{U} \text { - univerzalne mašine } & \rightarrow & \mathrm{S}_{\mathrm{z}}=0,00-0,34 \\ \mathrm{~S} \text { - specijalne mašine } & \rightarrow & \mathrm{S}_{\mathrm{z}}=0,34-0,67 \\ \mathrm{~A} \text { - automatizovane mašine } & \rightarrow & \mathrm{S}_{\mathrm{z}}=0,67-1,00\end{array}$

Međutim, bez obzira na globalnu podelu mašina na univerzalne (U), specijalne (S) i automatizovane (A), svaka grupa mašina ima različita tehnička rešenja $\mathrm{i}$ veoma veliki broj različiti zaštitnih sistema. Detaljnijom analizom postojeći konstruktivnih rešenja mašina $\mathrm{i}$ analizom aktivnosti koje obavlja radnik $\mathrm{u}$ odnosu na ugrađene sisteme zaštite, dolazi se do konstatacije da nelinearizovani zakon promene parametra stepena zaštite $\left(S_{z}\right)$, prikazan isprekidanom linijom na slici 3, više odgovara stvarnosti realizovanih tehničkih rešenja u praksi.

\section{KARAKTERISTIČNE OPASNOSTI I ŠTETNOSTI}

Opasnosti i štetnosti po intenzitetu dejstva menjale su se u zavisnosti od vremenskog perioda tehničko tehnološkog razvoja. Analiza intenziteta kasrakterističnih opasnosti i štetnosti koje su bile izražene u prošlom veku prikazana je dijagramom, slika 4 .

Početkom prošlog veka najizraženije su bile mehaničke opasnosti, dok su problemi psihofiziološke prirode bili beznačajni. Međutim, na kraju prošlog veka došlo je do promena $\mathrm{u}$ smislu negativnih faktora po bezbednost radnika. Intenzitet opasnosti od povreda mehaničkog dejstva je znatno manja, ali se zato znatno povećao intenzitet psihofizioloških problema sa tendencijom stalnog porasta, a sve zbog prelaska na nov automatizovan način proizvodnje.

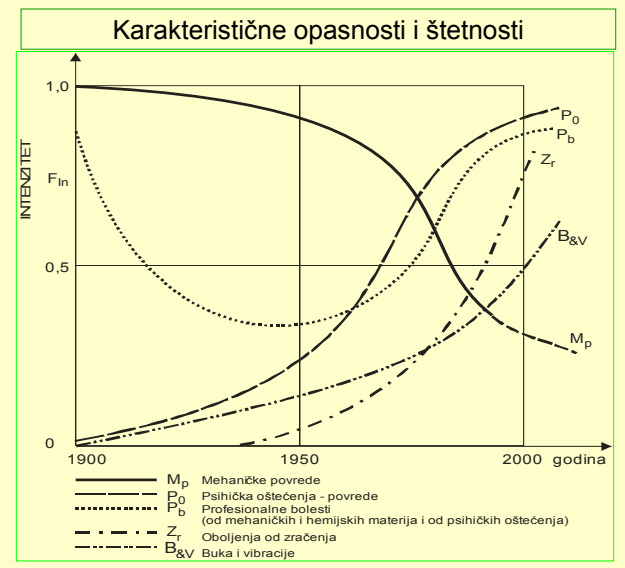

Slika 4. Dijagram promene intenziteta opasnosti $i$ štetnosti u dvadesetom veku

Dvadeseti vek je vreme u kome su automatizovani proizvodni sistemi doživeli svoj puni razvoj, naročito u drugoj polovini dvadesetog veka sa pojavom računara. $\mathrm{Na}$ osnovu analize uslova rada i tehničko-tehnološkog razvoja u prošlom veku može se konstatovati sledeće:

1) Čovek se automatizovanjem sredstava rada i tehnoloških procesa sve više udaljava iz opasnih zona, pri čemu su i povrede mehaničkog dejstva od pokretnih delova sredstava rada svedene na minimum ili su $\mathrm{u}$ pojedinim tehnologijama potpuno eliminisane. Kao rezultat razvoja automatizovanih sredstava rada $i$ tehnološkog napretka od polovine dvadesetog veka, parametar intenziteta opasnosti od mehaničkih povreda se smanjuje - što pokazuje i kriva na dijagramu - $\left(\mathrm{M}_{\mathrm{p}}\right)$, slika 4.

2) Izmenjeni su uslovi čovekovog opterećenja, jer se automatizacijom tehnoloških procesa i proizvodnje fizički napori radnika svode na minimum, dok se psihička opterećenja značajno uvećavaju. Ovo se manifestuje naglim porastom psiholoških oboljenja, što pokazuje kriva na dijagramu - $\left(\mathrm{P}_{\mathrm{o}}\right)$, slika 4 .

3) Automatizacija procesa dovodi do neslućenih razmera prerade svih vrsta materijala, što se manifestuje sve većim hemijskim i radijacionim zagađenjem radne i životne sredine. Posledica ovog stanja je veoma izražen porast intenziteta opasnosti od profesionalnih bolesti, što pokazuje kriva na dijagramu - $\left(\mathrm{P}_{\mathrm{b}}\right)$, slika 4 .

4) Primenom novih tehnologija pedesetih godina prošlog veka uticaj štetnog zračenja postaje sve izraženiji, što pokazuje kriva na dijagramu - $\left(Z_{\mathrm{r}}\right)$, slika 4.

5) Dominantan uticaj u narednom periodu ima štetno dejstvo buke i vibracija koja nastaju u procesu korišćenja sredstava rada, što pokazuje kriva na dijagramu-(B\&V), slika 4.

$\mathrm{Na}$ osnovu iznetih konstatacija dolazi se do saznanja da su se uzroci povređivanja radnika i ugrožavanja njegovog integriteta menjali u zavisnosti od:

- $\quad$ sredstava rada i proizvodnih tehnologija;

- organizacije rada;

- društveno-organizacionog sistema u domenu ekonomije, socijalnih odnosa, pravne regulative $\mathrm{i} d r, \mathrm{i}$

- $\quad$ promene stanja u biosferi.

Sredstva rada koja se koriste u procesu proizvodnje omogućavaju odvijanje tehnološkog procesa, ali ona istovremeno generišu opasnosti i štetnosti čiji se stepen može izraziti sledećom funkcionalnom zavisnošću:

$\mathrm{S}_{\mathrm{os̆}}=\mathrm{f}\left(\mathrm{M}_{\mathrm{o}}, \mathrm{E}_{\mathrm{o}}, \mathrm{F}_{\check{\mathrm{s}}}, \mathrm{H}_{\check{\mathrm{s}}}, \mathrm{K}_{\mathrm{os̆}}\right)$

gde su:

$\mathrm{S}_{\mathrm{oš}}$ - stepen opasnosti i štetnosti od sredstava rada;

$\mathrm{M}_{\mathrm{o}}$ - opasnosti od mehaničkih povreda radnika izazvane od pokretnih delova (npr. povrede ruku kada se iste nađu u opasnom radnom području);

$E_{o}$ - opasnosti od energije (električne energije, toplotne energije, i dr.);

$F_{\breve{s}}$ - fizičkih štetnosti koje nastaju u toku proizvodnog ciklusa (npr. buka, vibracije, zračenje);

$\mathrm{H}_{\check{s}}$ - hemijske štetnosti koje nastaju u tehnološkom procesu (npr. stvaraju se opasne materije $u$ tehnološkom procesu: gasovi para, prašina i slično) $i$ $\mathrm{K}_{\text {oš }}$ - kombinovane opasnosti i štetnosti.

Ako se posmatra pitanje bezbednosti radnika u pogledu njegove fizičke ugroženosti od sredstava rada $u$ proizvodnom procesu i mogućnosti da dođe do povređivanja, tada je produktivnost uslovljena povećavanjem stepena automatizacije sredstava rada. Može se zaključiti da savremena tehnička rešenja imaju pozitivan uticaj na bezbednost radnika, tj. na smanjenje rizika. 


\section{UTICAJ AUTOMATIZACIJE NA BEZBEDNOST I ZDRAVLJE NA RADU}

U dosadašnjem razvoju društva, međusobni odnos uloge čoveke u odnosu na mašinu moguće je identifikovati kroz tri koncepta: manufakturni, industrijski i računarsko-industrijski.

U zavisnosti od toga kakva je uloga čoveka u proizvodnom procesu rada mašine on može biti manje ili više ugrožen. Ugroženost radnika koji opslužuje mašinu zavisi od stepena njene automatizacije. Ukoliko se posmatra sistem ,čovek-mašina" kao kibernetski proces (proces prenošenja, primanja, obrade $i$ odavanja informacija u zatvorenom krugu), informacije se dele na one koja mašina pruža čoveku i one koje čovek pruža mašini. Pri tome je krug potpuno zatvoren, jer reakcija čoveka predstavlja ,ulazni podatak“ za mašinu, a dejstvo mašine i signalnih uređaja ,ulazni podatak“ za čoveka, kao što je prikazano na slici 5.

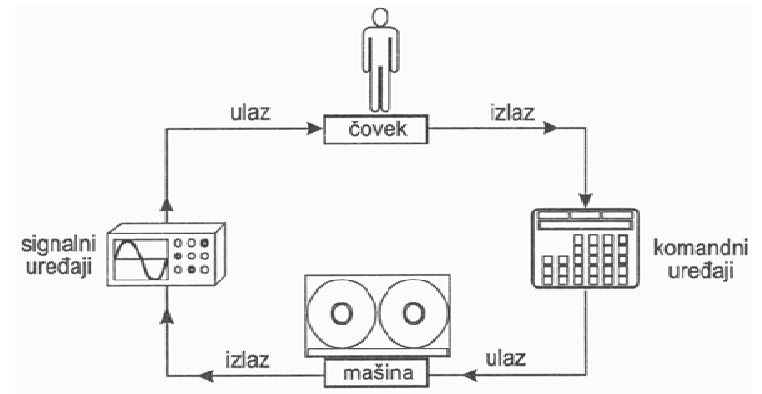

Slika 5. Šematski prikaz razmene informacija u sistemu , čovek-mašina"

Ulazne podatke čovek prima percepcijom od strane signalnih uređaja mašine. $\mathrm{Na}$ signalnim uređajima se očitavaju podaci za donošenje odluke na koju reaguje čovek. Međutim, osim podataka koje daju signalni uređaji mašine, čovek prima i dopunske ulazne podatke iz spoljne sredine, koji utiču na njegovo ponašanje $u$ procesu rada. Ti spoljni ulazni podaci iz radne sredine (prevelika toplota ili hladnoća, buka i vibracije, loše osvetljenje, prekor od strane rukovodioca i slično), negativno utiču na radnika i mogu prouzrokovati smanjenje koncentracije pri radu uz povećanje njegove ugroženosti.

Automatizacija industrijskih procesa uz miniminiziranje prisustva čoveka na rutinskim poslovima u proizvodnji predstavlja davnašnju želju i stalni trend $u$ tehničko-tehnološkom razvoju. Automatsko odvijanje procesa proizvodnje i automatsko upravljanje, pored toga što oslobađa čoveka od rutinskog rada, obezbeđuje mu time dovoljno vremena za kreativne delatnosti i utiče pored ostalog, na tri bitna elementa, i to na:

- povećanje produktivnosti;

- podizanje kvaliteta proizvoda $\mathrm{i}$

- ostvarenje pozitivnih ekonomskih efekata.

Analizom motiva koji su doveli do razvoja mehanizacije $\mathrm{i}$ automatizacije u proizvodnji, mogu se izdvojiti sledeći razlozi:
- smanjenje ili eliminisanje udela teškog rada u prizvodnom procesu;

- eliminisanje ugroženosti čoveka od sredstava rada, odnosno, stvaranje bezbednih uslova rada $\mathrm{u}$ proizvodnji, kao i eliminisanje mogućih povreda;

- zaštita zdravlja radnika u procesu proizvodnje;

- ekonomski razlozi, radi ostvarenja što većih ekonomskih efekata - dobiti;

- tehnički razlozi kako bi se prevazišli problemi koji proizlaze iz ograničenih mogućnosti i sposobnosti čoveka, i

- tržište radne snage, tj. problem nedostataka kvalifikovane radne snage.

Automatizacija industrijskih procesa, uz minimalno prisustvo čoveka u proizvodnji, predstavlja stalni trend u razvoju proizvodnih odnosa. Automatsko odvijanje procesa proizvodnje i automatsko upravljanje, pored toga što oslobađa čoveka od rutinskog rada, obezbeđuje mu dovoljno vremena za kreativne delatnosti. U automatizovanim procesima mašina je brža, preciznija, snažnija ali manje prilagodljiva, dok je čovek sporiji, sklon greškama, relativno slab, ali je zato prilagodljiv na promenljive situacije u procesu rada.

Prva razmatranja o automatizaciji tehnološkog sistema bila su vezana za optimalan način proizvodnje od strane čoveka, a kasnije za korišćenje adekvatnih sredstava rada. Automatizacija je pri tome tretirana kao stepen na kome je čovekov rad zamenjen sredstvima rada, a meren proizvodnjom, odnosno, proizvodima kao izlaznim rezultatom iz sistema. Međutim, za objektivnu ocenu proizvodnih sistema različitih nivoa automatizacije neophodno je pored poznavanja proizvodnih rezultata, izraženih proizvodima, sagledati i sve druge faktore koji se direktno ili indirektno održavaju na čoveka i utiču na kvalitet njegovog življenja, kao što su: zaštita radnika u procesu proizvodnje, kvalitet radne i životne sredine, psihofizičko angažovanje i opterećenje radnika, kao i odraz na njegovo zdravlje i rizik kojem je izložen.

Novi način proizvodnje bazira se na: znanju, novim materijalima i novim tehnologijama, principima kvaliteta u svim fazama realizovanja proizvoda pri čemu u svim fazama i na svim mestima dominira primena računara. Iz ovoga se može konstatovati da primena računara omogućuje automatizaciju proizvodnih sistema sa stalnom tendencijom stvaranja fleksibilnih, visoko-automatizovanih i visokoproduktivnih proizvodnih sistema.

Da bi se olakšao težak rad, sve je veća primena robota i automatizovanih proizvodnih jedinica, a sve manje prisustvo čoveka u industrijskoj proizvodnji. $\mathrm{Na}$ ovaj način čovek se sve više udaljava od sredstava rada $\mathrm{i}$ njegov rad se svodi na upravljačke i kontrolne funkcije pomoću računara. Međutim, pored dobrih, postoji i niz negativnih posledica:

- Korišćenje računara primorava čoveka da sedi u prinudnom položaju za vreme radnog vremena i pri tome prati šta se dešava na ekranu monitora ili tipka po 
tastaturi. Sve vreme oči su opterećene, kičma ugrožena a zglobovi ruku takođe opterećeni, što se manifestuje porastom obolevanja i oštećenja organa vida, kičme i zglobova ruku.

- Pored pomenutih fizičkih, postojem i nepovoljne štetne posledice psihičke prirode. Sedeći za računarom radnik vremenom gubi moć uočavanja razlike između iluzije i stvarnosti, sve se više otuđuje od prirode i udaljava od druženja.

\section{ZAKLJUČAK}

Stalnim razvojem tehničko tehnoloških sistema menja se koncept uloge čoveka u odnosu na korišćenje mašine: prvo je mašina bila pomoć čoveku u proizvodnom procesu, zatim je čovek postao upravljač mašine i konačno čovek postaje monitor mašine. „Čovek je stvorio mašinu, ali mašina je zarobila čoveka i čovek radi ali ne živi više“ - (Gandi).

Razvoj elektronike i mikroprocesora, i na njima nastale informacijske tehnologije omogućio je skoro potpunu zaštitu fizičkog integriteta čoveka u radnoj sredini. Međutim, brz tehničko-tehnološki razvoj redukovao je pokretne funkcije čoveka uz produžavanje vremena sa statičkim opterećenjima i nervnom napetošću. Vekovni zahtevi čoveka vezani za fizičku zaštitu na radu sada su zadovoljeni, ali se javljaju daleko ozbiljniji problemi koji dovode do psiholoških poremećaja i obolevanja, kao i ugrožavanja radnika bez obzira na njihov odnos prema proizvodnom sistemu.

U naučnim krugovima sve oštrije i glasnije se postavlja pitanje - Da li će čovek postati sluga tehnologije ili će tehnologija služiti čoveku?

Na kraju se može zaključiti da i pored stalnog razvoja tehničko-tehnoloških sistema, još uvek nema apsolutno bezbednih, koji bi omogućavali obavljanje radnih operacija a da radnik nije ugrožen. Razlog za neadekvatno rešavanje problema bezbednosti sadržan je u kompleksu mnogobrojnih subjektivnih faktora koji se odnose na čoveka i objektivnih faktora koji se odnose na tehničko-tehnološka rešenja.

\section{LITERATURA}

[1] Janković Žarko: Tehnički sistemi zaštite, pomoćni užbenik, Univerzitet u Nišu, Fakultet zaštite na radu u Nišu, 2011.

[2] Janković Žarko: Razvoj tehničkih sistema zaštite, Nacionalna konferencija sa međunarodnim učešćem, Zbornik radova, str. (132-143), Fakultet zaštite na radu u Nišu, mart 2010.

[3] Janković Žarko: Rizik od opasnosti mehaničkog dejstva, 1. Međunarodna naučna konferencija "Bezbedonosni inženjering" i 11. Međunarodna konferencija "Zaštite od požara i eksplozije", Zbornik radova, str. (479-486), Novi Sad, oktobar 2008.

[4] Zeljković, V., Đapić, M., Janković, Ž.: Machine Safety and Mechanical Hazards, International Conference "Dependability and Quality Management”- DQM 2006, pp.(492-497), Belgrade, 2006.

[5] Encyclopaedia of occupational health and safety, fourth edition, Volume II, Accidents and safety management, Moving Parts of Machines (58.858.11), Machine Safeguarding (58.11 - 58.27), International labour office, Geneva, 1998.

\section{BIOGRAPHY}

Žarko Janković was born in Zenica, Bosnia and Hercegovina, in 1952.

$\mathrm{He}$ received the diploma in occupational safety engineering and the $\mathrm{Ph} . \mathrm{D}$. degree in technical safety systems from the University of Nis, Faculty of Occupational Safety.

His main areas of research include safety of technical systems, occupational health and safety, technical safety of fire safety, etc. He is currently working as a full professor at the Faculty of Occupational Safety in Nis, University of Nis.

\title{
THE INFLUENCE OF TECHNICAL AND TECHNOLOGICAL DEVELOPMENT ON SAFE WORKING CONDITIONS
}

\section{Žarko Janković}

\begin{abstract}
The concepts of technical and technological development and their impact on safe working conditions have been analyzed in this paper. In order to understand the problem of improving occupational safety and health in terms of the development of technological systems, various concepts of manufacturing processes have been explained - starting from manufacturing, industrial and computing industrial to full automation of manufacturing processes. Throughout these periods, work conditions were changing with the aim to reduce physical exertion, while the psychological stress increased. Particular emphasis has been given to the impact of automation on occupational safety and health. The author pointed to the potential problems imposed by new modern production technologies.
\end{abstract}

Key words: technological development, automation, occupational safety. 